\title{
The recent collapse of a rapid phase-shift reversal on a Jamaican north coast coral reef after the 2005 bleaching event
}

\author{
N.J. Quinn ${ }^{1,2} \&$ B.L. Kojis 1,3 \\ 1. Discovery Bay Marine Lab, University of the West Indies, Discovery Bay, St. Ann, Jamaica \\ 2. Present address:, Department of Planning and Natural Resources, St. Croix East End Marine Park, 45 Mars Hill, \\ Frederiksted, U.S. Virgin Islands 00841 FAX 340-777-8151.norman.quinn@dpnr.gov.vi \\ 3. Present Address: Division of Science and Math, University of the Virgin Islands, \#2 Brewer's Bay, St. Thomas, U.S. \\ Virgin Islands 00802
}

Received 15-VII-2007. Corrected 01-XI-2007. Accepted 13-II-2008.

\begin{abstract}
The community structure of most Caribbean reefs has changed dramatically since the 1980s. Invoking a chemistry analogy, in 1994 Hughes termed the change a "phase shift" to describe the change from a coral dominated habitat to one dominated by macroalga on the north coast of Jamaica over a period of 17 years. The loss of live coral cover is exemplified by the demise of Acropora spp. in Discovery Bay, Jamaica. Dense, monospecific high relief thickets of Acropora palmata (elkhorn coral) and A. cervicornis (staghorn coral) were characteristic of shallow and intermediate depth coral communities in the Caribbean prior to the late 1970s. In the early 1980s, A. cervicornis live coral cover was $>21 \%$ at several sites around Discovery Bay, by 1987 it had declined to less than 1\%. No large population of Acropora reestablished in the vicinity of Discovery Bay for nearly two decades. In 1995, A. cervicornis cover at Dairy Bull Reef (DBR) was only 0.6\%. By 2004, A. cervicornis cover had increased to about $10.5 \%$. In 2005, A. cervicornis cover further increased to $44 \%$. This increase in A. cervicornis cover was part of the important "phase shift reversal" reported by Idjadi et al. in 2006. An isolated population of $A$. cervicornis exhibited similar coral cover at East Rio Bueno (ERB). In 2005, both populations of $A$. cervicornis bleached; however, the two populations responded differently. The population at DBR was decimated by the bleaching event and the surviving remnants were attacked by Coralliophila. At DBR, cover declined to $<0.5 \%$ by June 2006 . The population at ERB recovered from the bleaching event with little decrease in cover. Coral recruitment was examined over three spawning periods on DBR. Only two Acropora spat recruited to settlement tiles - one in 2003 and one in 2005. Acropora recruitment represented only $0.7 \%$ of the total spat recruiting to the tiles during the entire sampling period. Rev. Biol. Trop. 56 (Suppl. 1): 149-159. Epub 2008 May 30.
\end{abstract}

Key words: Acropora cervicornis, restoration, recruitment, planulae.

Four decades ago Goreau and Goreau (1973) documented Caribbean coral reef community structure on north coast Jamaican reefs. The importance of their studies became increasingly recognized as shallow water live coral cover declined throughout the region and the acroporids became locally extinct on many reefs (Knowlton et al. 1990). In fact, their work was used as a standard by which coral reefs were measured throughout the Caribbean.
Prior to 1980, Acropora cervicornis was abundant at the West Fore Reef at Discovery Bay (Goreau and Wells 1967, Tunnicliffe 1983). However, in the 1980's, the cover of A. cervicornis was reduced from $53 \% \pm 10 \%$ to a negligible presence by Hurricanes Allen (1980) and Gilbert (1988) (Woodley et al. 1981, Crawford 1995, Woodley 1991). Recovery of A. cervicornis after Hurricane Allen was impeded by high mortality of surviving fragments caused 
by disease (Knowlton et al. 1981). During the past 25 years, there has been no wide - spread increase in A. cervicornis due to disease and predation (Bruckner et al. 1997) and the low rate of sexual recruitment characteristic of this species (Sammarco 1980, Tunnicliffe 1981). This naturally low sexual recruitment rate has been exacerbated by the decline in the abundance of the reproductive adult population (Kojis and Quinn 1993, 2001, Quinn and Kojis 2005, 2006a, 2006b).

Hughes (1994) used the term "phase shift" to describe the change from a coral dominated to an algal dominated reef community on the north coast of Jamaica near Discovery Bay. The recent rapid increase in live coral cover, particularly in the abundance of $A$. cervicornis, at Dairy Bull Reef on the north coast of Jamaica, suggested that a "phase shift reversal" from an algal dominated to a coral dominated reef community was possible (Idjadi et al. 2006). However, in 2005 a severe bleaching event impacted reefs on the north coast of Jamaica. This paper describes the impact of the 2005 bleaching event on the Dairy Bull Reef corals, with an emphasis on the impact on $A$. cervicornis, and compares these results to those at the nearby east Rio Bueno reef.

\section{MATERIALS AND METHODS}

Water Temperature: A Hugrun Seamon brand underwater temperature recorder with an absolute accuracy of $\pm 0.05^{\circ} \mathrm{C}$ was deployed at a depth of $8 \mathrm{~m}$ at Dairy Bull Reef (DBR) (18 $28.04^{\prime}$ $\left.\mathrm{N} ; 7^{\circ} 23.10^{\prime} \mathrm{W}\right),<2 \mathrm{~km}$ from the West Fore Reef (WFR) site $\left(18^{\circ} 28.17^{\prime} \mathrm{N}\right.$; $\left.77^{\circ} 24.49^{\prime} \mathrm{W}\right)$, from 21 December 2000 to 15 May 2002. It recorded 11,707 hourly subsurface seawater temperature (S3T) observations. The UTR was placed adjacent to a rich coral reef community $\sim 5 \mathrm{~cm}$ above the seabed to allow for a good flow around the recorder. The recorder was moved to the WFR (depth: $11 \mathrm{~m}$ ) and recorded 27,735 hourly S3T observations from 2 November 2002 to 31 December 2005. The sites were considered similar and the data pooled. Gaps in both data sets were the result of equipment failure.
Coral Recruitment: Coral recruitment arrays were constructed by attaching four 208 $\mathrm{cm}^{2}$ unglazed terracotta tiles to a PVC array. The tiles were smooth on one side and had 12 ridges on the other side. Two tiles were oriented horizontally and two vertically on each array. Paired arrays were installed at DBR at $9 \mathrm{~m}$ depth with the tiles $\sim 0.8 \mathrm{~m}$ above the substrate in early April 2003. They were replaced eight months later in December 2003 ("summer 2003" sampling period), ten months later in late October 2004 ("winter / summer 2004"), nine months later in July 2005 ("winter 2005") and finally collected four months later in November 2005 ("summer 2005"). After removal from the site, the tiles were fixed in formalin and bleached. Scleractinian corals were counted (standardized to number recruits $\mathrm{m}^{-2}$ ) and identified to family where possible using a binocular microscope.

Coral Surveys and Bleaching: Structured quantitative surveys were conducted between September 2005 and June 2006 along $20 \mathrm{~m}$ transect lines parallel to the depth contours at the $7-10 \mathrm{~m}$ depth range at DBR $(n=10)$ and at East Rio Bueno (ERB) $(n=8)\left(18^{\circ} 28.47^{\prime}\right.$ $\left.\mathrm{N} ; 77^{\circ} 25.50^{\prime} \mathrm{W}\right)$. The structured quantitative surveys consisted of recording data at $0.5 \mathrm{~m}$ intervals under the transect line in accordance with standard Reef Check protocol (Hodgson and Liebeler 2002). Additionally, when corals were encountered, the species was identified and the following attributes recorded: presence or absence of bleaching, percent of colony bleached, and evidence of recent presence of predators. If the coral was recently killed, this was recorded this as well. The percentage of coral colonies bleached and the average percentage of bleaching $1 \mathrm{~m}$ on each side of each transect line was estimated. Qualitative assessment of overall bleaching was carried out from September 2005 to June 2006 during 60-75 min dives $(n=25)$ by estimating the percentage of colonies bleached at depths 2-35 m. Photos representative of the coral community at each survey location were taken both along the Reef Check transects and during the random 
surveys and subsequently used in the analysis. From the photos the percent bleaching of the dominant coral present in each photo was estimated. Based on all three data sets, the extent of bleaching was determined.

\section{RESULTS}

Water temperature: The daily subsurface seawater temperature (S3T) was higher from mid May to mid October 2005 than for this period in each of the years 2001-2004 (Fig. 1). The mean monthly S3T from April to November 2005 was above the mean monthly temperature for April to November 2001-2004 (Fig. 2). Mean monthly S3T in 2005 remained at least $0.69^{\circ} \mathrm{C}$ warmer than the mean for the previous four years from April through October (Table 1) with the greatest difference between the mean monthly S3T in May $\left(1.05^{\circ} \mathrm{C}\right)$ and September $\left(0.88^{\circ} \mathrm{C}\right)$. The warmest $\mathrm{S} 3 \mathrm{~T}$ recorded during the five years of this study was $30.45^{\circ} \mathrm{C}$, which occurred at $17: 00 \mathrm{hr}$ on 29 September 2005, a couple of weeks after the initial observation of the onset of bleaching. The period mid May to mid October was characterized by calm seas and clear to partly cloudy days (pers. obs.).
Coral Recruitment: Spat from the family Poritidae were the most common $(39.7 \%)$ at Dairy Bull Reef (DBR) followed by unidentifiable spat (25.2\%), Agariciidae (23.2\%), Milleporidae (11.3\%) and Acroporidae (0.7\%). Of the 302 Scleractinia and Millepora spat recorded on settlement plates at DBR, two acroporid recruits were observed, only one of which was large enough to identify to species. The identifiable recruit was an Acropora cervicornis $8.5 \mathrm{~cm}$ in length. It recruited to a tile that was deployed for 8.5 months (from 25 Oct 04 to 11 July 05 ), exhibiting an annualized growth rate of at least $12 \mathrm{~cm}$ year $^{-1}$.

Coral Bleaching: At the beginning of 2005, the scleractinian live coral cover at DBR was high, creating a structurally complex and visually appealing reef. Of the $56 \%$ total live coral cover, $44 \%$ was $A$. cervicornis. In early September 2005, the onset of bleaching was first observed in colonies of the Montastraea annularis complex when portions of colonies began to pale or turn white (Fig. 3). By mid September all species of scleractinan coral at DBR (except Dendrogrya cylindrus) showed some signs of bleaching.

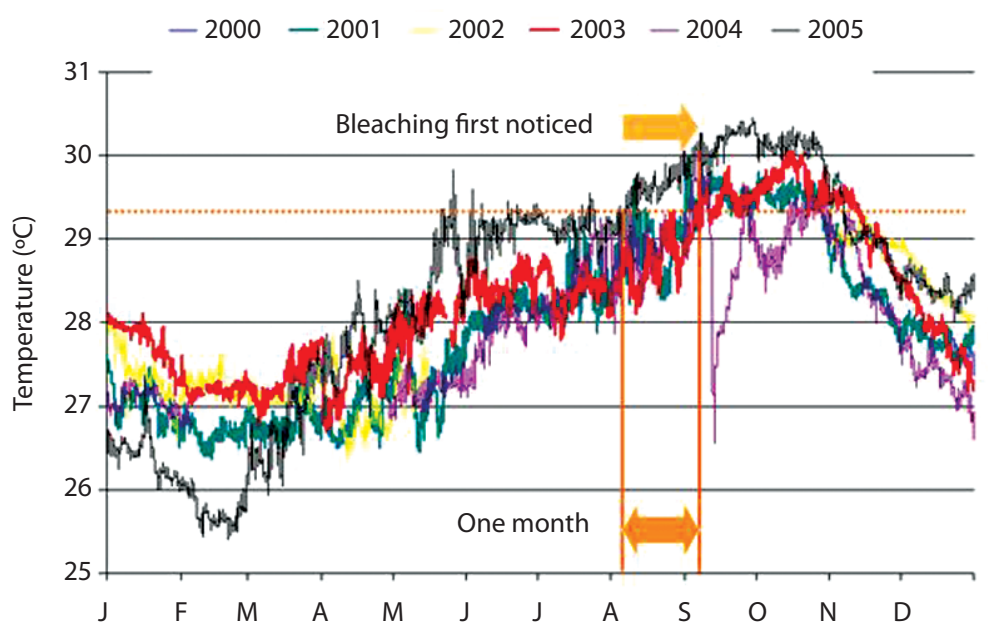

Fig. 1. Mean monthly subsurface sea water temperatures 21 December 2000 - 31 December 2005 (modified from Quinn and Kojis 2003a). 


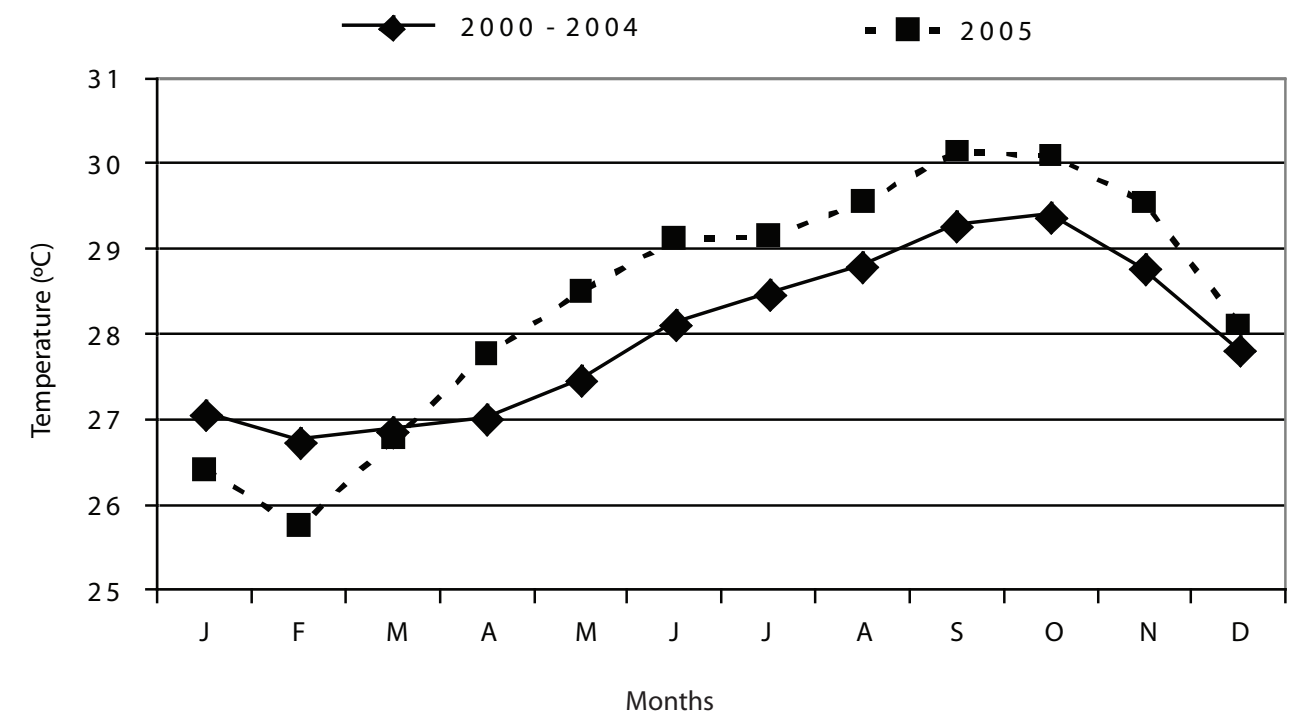

Fig. 2. Comparison of 2005 mean monthly subsurface sea water temperature with mean temperatures from 21 December 2000 - 31 December 2004.

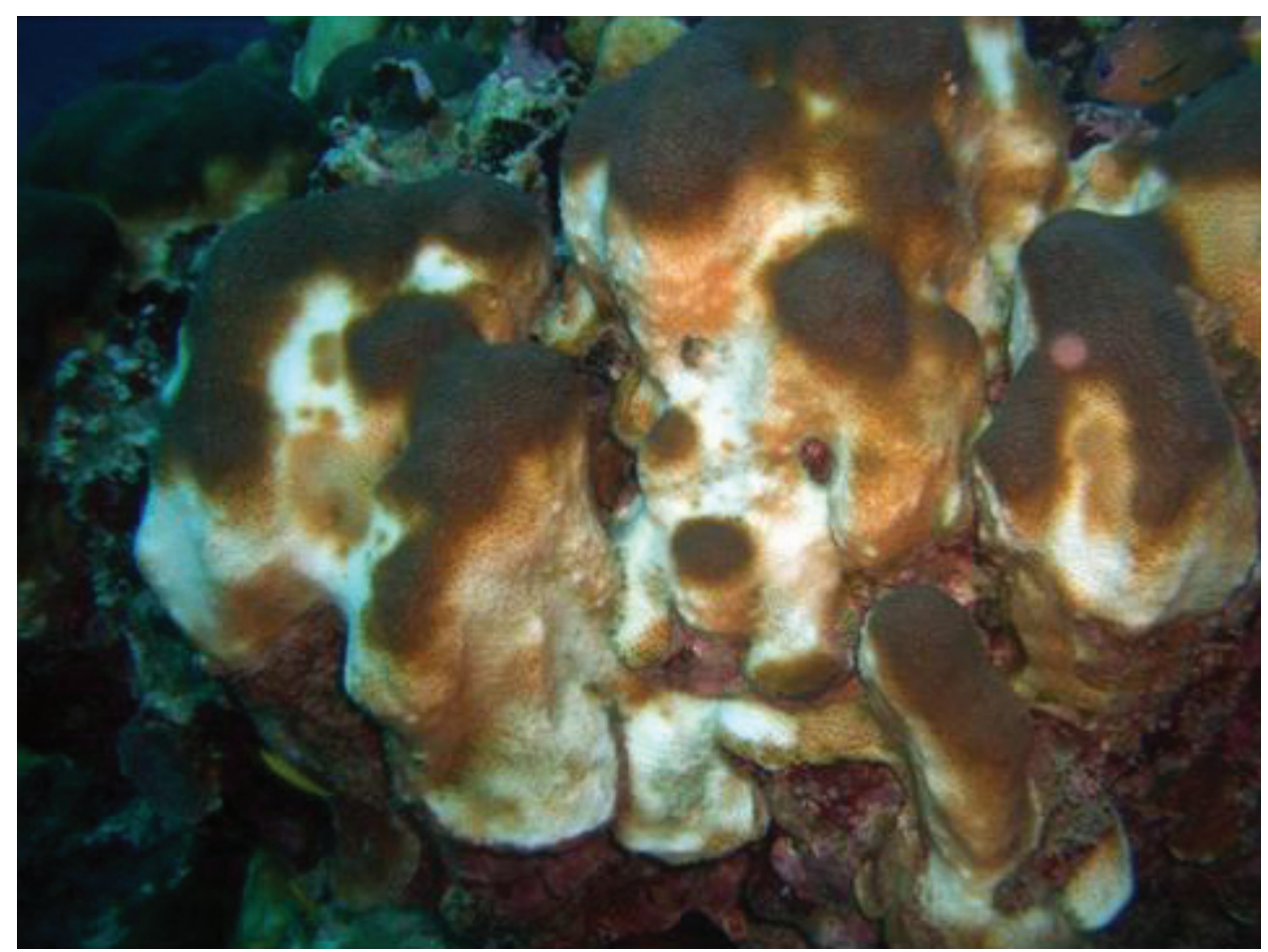

Fig. 3. Montastrea annularis at initial stages of bleaching in September 2005 at $9 \mathrm{~m}$ at Dairy Bull Reef. 


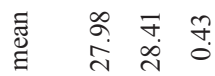

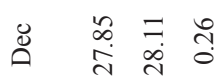

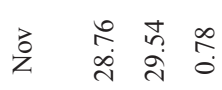

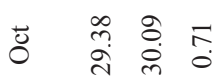

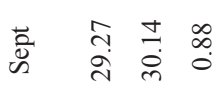

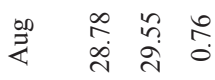

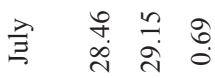

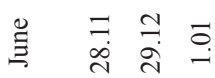

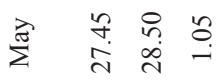

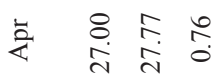

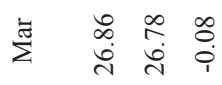

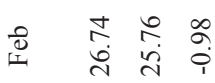

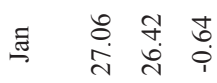

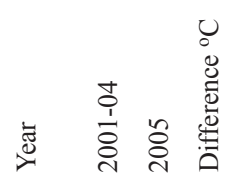

From October to December 2005, the percentage and degree of colonies bleached of each species varied widely (Table 2a, 2b). However, more than $50 \%$ of colonies of most species bleached at DBR and ERB with more than $95 \%$ of colonies of A. cervicornis, Agaricia spp., Leptoseris cucullata, Meandrina meandrites, M. annularis, Porites spp., Siderastrea siderea and Acropora spp. bleaching. Only A. cervicornis exhibited $100 \%$ bleaching at both sites with $100 \%$ of colonies bleached totally white (Table 2a, b).

Mortality varied widely between species and sites. In late December 2005 / January 2006, the highest mortality from bleaching was exhibited by A. cervicornis at DBR with $90 \%$ mortality (Table 2a). In contrast, $A$. cervicornis at ERB reef exhibited only $10 \%$ mortality (Table 2b). A. palmata colonies at West Rio Bueno recovered from the bleaching, but were observed being preyed upon by the coral snail, Coralliophila abbreviata, in February 2006. Mortality was readily noted because filamentous algae were beginning to cover the skeletons of recently killed coral.

In February, 2006, surviving remnants of A. cervicornis at DBR were observed to be preyed upon by the Coralliophila abbreviata. There was also evidence of predation by the bearded fire worm (Hermodice carunculata). Predation on $A$. cervicornis by these two species was not observed at ERB.

From February to June 2006, the remaining live tissue on surviving bleached colonies, including A. cervicornis, began to progressively regain its natural color. However, by June 2006 at DBR, there was less than $<0.5 \%$ live coral cover of A. cervicornis (Fig. 4).

\section{DISCUSSION}

Idjadi et al. (2006) described a "phase shift reversal" on Dairy Bull Reef (DBR) in which live coral cover increased to 1970 levels and macroalgal cover decreased to levels recorded prior to Diadema mortality of 1983-84. They declared that the benthic community at DBR in 2004 was reminiscent of the fore reef 
TABLE 2A

Percentage of colonies bleached and average degree of bleaching for some common scleractinians, gorgonians and sponges observed from Sept. 2005 - Feb. 2006 at Dairy Bull Reef

Species

\section{Scleractinia}

Acropora cervicornis

Acropora palmata

Agaricia lamarcki

Agaricia agaricites

Colpophyllia natans

Diploria strigosa

Dendrogyra cylindrus

Leptoseris cucullata

Madracis decactis

Meandrina meandrites

Montastraea annularis complex

Montastraea cavernosa

Porites astreoides

Porites porites

Siderastrea siderea

Siderastrea radians

Stephanocoenia intersepta

\section{Gorgonians}

Eunicea calculata

Plexaurella nutans

Pseudopterogorgia sp

\section{Sponges}

No evidence of bleaching
$\%$ of colonies bleached

Degree of bleaching

Colony mortality related to bleaching

$\begin{array}{lcc}100 \% & \text { totally white } & 90 \% \\ 100 \% & \text { Totally white } & \text { Occasional colonies completely dead, } \\ \text { mostly PM50 } & \text { PM50 } \\ 95 \% & \text { totally white } & \text { PM50 } \\ 95 \% & \text { totally white } & \text { PM50 } \\ 66 \% & \text { pale to totally white } & \text { very rare } \\ 66 \% & \text { pale to medium } & \text { none } \\ 50 \% & \text { slight paleness } & \text { PM50 } \\ 95 \% & \text { totally white } & \text { PM50 } \\ 60 \% & \text { pale } & \text { none } \\ 95 \% & \text { severe }- \text { mostly white } & \end{array}$

$99 \% \quad$ very pale to totally white

$5 \% \quad$ some colonies pale spots

$100 \%$

$99 \%$

$95 \%$

$50 \%$

$50 \%$

$5 \%$

$5 \%$

$0 \%$

$0 \%$ slight color change

severe

severe - colonies colored pale

blue

severe - colonies colored pale

blue

pale

Data blended from surveys described in Materials and Methods.

Legend: Partial mortality in $\leq 25 \%$ of the colonies, PM25; partial mortality in $>25 \%$ and $\leq 50 \%$ of the colonies, PM50; partial mortality in $>50 \%$ of the colonies, PM75. 
TABLE 2B

Percentage of Acropora cervicornis and A. palmata colonies bleached observed from Sept. 2005 - Feb. 2006 at Rio Bueno Reef

Species

$\%$ of colonies bleached

Degree of bleaching

Colony mortality related to bleaching

Acropora cervicornis

$100 \%$

Totally white

$10 \%$

Acropora palmata

$100 \%$

Totally white

$15 \%$

Data blended from line transects and random photo surveys.

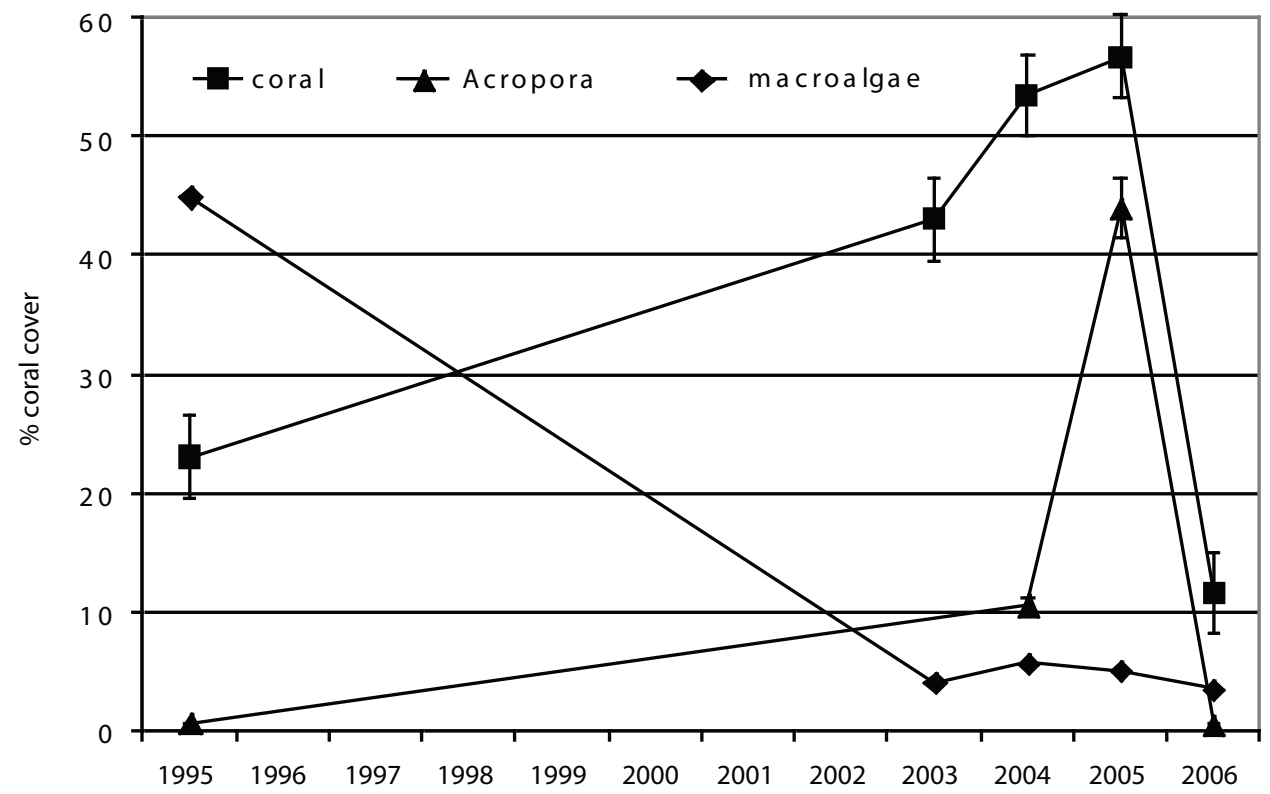

Fig. 4. Mean percentage cover of: live coral, Acropora spp., and macro algae at Dairy Bull Reef, in 1995, 2003,2004 (from Idjadi et al. 2006), 2005 and 2006 this study. Bars represent SE.

community structure present at Discovery Bay prior to Hurricane Allen with dense thickets of Acropora cervicornis lodged between colonies of Montastraea annularis and surmised that colonies of M. annularis provided topographic complexity that may have facilitated the recovery of the DBR reef. The term "phase shift" was originally used to describe the overgrowth of north coast Jamaica coral reefs in 1983 by algae associated with the mass die off or the sea urchin, Diadema antillarum (Hughes 1994). Other work on long term changes of coral reefs all around Jamaica concluded that the sites that
Hughes studied gradually became eutrophic in the early 1980s, while coral reefs on other parts of Jamaica also transitioned from coral to algal dominated reefs between the 1950 s to the 1990s depending on the increase of the local human population and influx of sewage effluents (Goreau 1992).

In 2005, the reefs on the north coast of Jamaica near Discovery Bay were heavily impacted by a bleaching event. The summer of 2005 was unusual in that there were extensive periods of low wind velocity, clear skies, calm seas and low turbidity. These conditions 
favored localized warming and high penetration of ultra violet radiation (UVR). It is most likely that the prolonged, unusually warm seawater temperature, exceeding $\geq 29.3^{\circ} \mathrm{C}$ for one month, the predicted threshold for inducing bleaching (Goreau et al. 1993), was the major cause of the 2005 bleaching event. In $2005,29.3^{\circ} \mathrm{C}$ was first recorded on May 22, which was the earliest that this temperature had been observed in the period $2001-2005$ (Fig. 1) (Quinn and Kojis 2003a). Although the temperature remained above $29^{\circ} \mathrm{C}$ during June and July, a month of consecutive daily temperatures exceeding $29.3^{\circ} \mathrm{C}$ did not accrue until September 7. Coral bleaching was first observed on a dive conducted on the same date.

After the bleaching event of 2005, live coral cover at DBR decreased dramatically to well below the pre "phase shift reversal" levels recorded by Idjadi et al. (2006). Total live coral cover declined from $56 \%$ in 2005 to $11 \%$ in 2006. In fact, the 2006 level was $12 \%$ less than the $23 \%$ cover recorded in 1995 by Idjadi et al. (2006).

Acropora cervicornis was a major contributor to the increase in live coral cover reported by Idjadi et al. (2006) at DBR, comprising nearly $20 \%$ of the total live coral cover. In 2005 (this study), total live coral cover was similar to 2004 , while $A$. cervicornis now comprised $>75 \%$ of the live coral cover. Although, the different survey methodology used in this study may have contributed to the $>50 \%$ increase in A. cervicornis abundance recorded in 2005 (Fig. 4), there are other factors that may have contributed to the decline in the contribution of other coral species to total live coral cover and the rapid increase in A. cervicornis. During 2003-2004, black band disease infected many M. annularis colonies and killed large sections of many colonies (Quinn, personal obs.). This event was overshadowed by the massive increase in A. cervicornis at DBR. With its high growth rate and branching structure $A$. cervicornis was able to rapidly cover large areas of the reef obscuring smaller species during transect surveys and giving the impression of a dynamic, healthy reef while masking the decline in the M. annularis population.

Surveys conducted in late June 2006 revealed that $<0.5 \%$ of the $A$. cervicornis population at DBR was still alive. The high mortality of A. cervicornis from the 2005 bleaching event and subsequent predation of the scattered remnants of live tissue by Coralliophila and Hermodice explains most of the decline in live coral cover at DBR, since A. cervicornis provided the majority of live coral cover.

In contrast, the population of $A$. cervicornis at East Rio Bueno (ERB) had much less mortality. Live coral cover declined only $8 \%$, from $47 \%$ in April 2004 to 39\% in January 2006. The intermittent high levels of turbid water from the Rio Bueno River may have protected the colonies at ERB from UV radiation, which possibly worked synergistically with temperature to cause bleaching of corals in clear water (Jokiel 1980, Gleason and Wellington 1993). As well, the cooler river water may have helped to moderate an increase in S3T at this site. Bleaching could also have been mitigated by the high algal cover at this site. Algal cover dominated by a Rhodophyta assemblage at ERB was high in 2005 and remained high in 2006.

While the 2005 bleaching event around DBR was extensive, it was unlike the events occurring on the bleached reefs of the U.S. Virgin Islands as no outbreak of disease (Miller et al. 2006) or overgrowth of the encrusting tunicate Trididemnum solidum were observed (pers. obs.). Also, at the Jamaican study sites total mortality was low for many coral species (Table 2a, b).

This study documents a very different interpretation of the factors influencing the "phase shift" changes. Elevated subsurface sea water temperatures apparently alter the population structure and diversity of a coral reef much fast than eutrophication, over fishing and herbivore mortality. As well, the recovery of DBR will likely be inhibited by the severe impact of bleaching on key species associated with the "phase shift reversal" described by Idjadi et al. (2006). Because A. cervicornis reproductive strategy emphasizes asexual fragmentation 
over sexual recruitment (Tunnicliffe 1981) and the remaining populations are so small and subject to intense predation, it is considered unlikely that acroporids will rapidly recover at DBR. A site inside Discovery Bay with a formerly large population of $A$. cervicornis has not recovered in almost three decades (Wapnick et al. 2004).

The reasons for the lack of recovery of the acroporids on the north coast of Jamaica are myriad but doubtlessly include the severe reduction in gamete producing adults (Quinn and Kojis 2006a) and the low survival of fragments due to predation. During a 49 month period only seven acroporid spat recruited to terracotta tiles deployed at $3 \mathrm{~m}$ and $9 \mathrm{~m}$ on the WFR (Quinn and Kojis 2006b) and during 32 months only a two acroporid spat recruited at DBR. Acroporid settlement represented $0.7 \%$ of the total coral settlement during the entire sampling period. In contrast, recruits of Poritidae and Agariciidae were abundant on settlement plates and these two species can be expected to rebound fairly quickly after a bleaching event at the Jamaican sites, if a sufficient number of colonies survive.

Acroporidae spat settlement rates in the Caribbean are commonly lower than other coral families (Rylaarsdam 1983) in the region and much lower than Acroporidae settlement rates on reefs in the South Pacific (Kojis and Quinn 2001, Quinn and Kojis 1999, 2003b). Current observations suggest that the long-term survival of $A$. cervicornis is threatened by a number of factors including bleaching, disease, predation, and a low rate of sexual recruitment (Knowlton et. al. 1981, Woodley et al. 1981). Given the overall severe decline and local extinction of populations of $A$. cervicornis, it is unlikely that this species will recover unless successful recruitment of sexually produced planulae occurs.

\section{ACKNOWLEDGMENTS}

This publication was made possible through support provided by the National Institutes of Health through the University of Mississippi under the terms of agreement No. R21 TW006645 funded by the Fogarty International Center and the National Institute for Research Resources for the International Cooperative Biodiversity Groups. The opinions expressed herein are those of the authors and do not necessarily reflect the views of the National Institutes of Health or the University of Mississippi. We are grateful for the use of the facilities of the Discovery Bay Marine Laboratory, University of the West Indies. The manuscript was greatly improved by the constructive comments from T. J. Goreau, C. Morrall and S.C. Steiner. Additional financial support was provided by Tropical Discoveries Fund. Peace Corps Volunteer C. Rhoads and T. Downes kindly assisted on several of the dives. This is Discovery Bay Marine Laboratory publication \#751. John Farchette III is gratefully acknowledged for translating the abstract.

\section{RESUMEN}

La estructura de la comunidad de la mayoría de los arrecifes del Caribe ha cambiado dramáticamente desde la década de 1980. Invocando una analogía de la química, Hughes llamó en 1994 a este fenómeno un "cambio de fase" para describir el cambio de un hábitat dominado por corales a uno dominado por macroalgas en la costa del norte de Jamaica. La pérdida de cobertura coralina es ejemplificada por la muerte de Acropora spp. en Discovery Bay, Jamaica. Antes de 1970, eran características de las comunidades coralinas de profundidades bajas e intermedias caribeñas, las acumulaciones densas, altas y monoespecíficas de Acropora palmata (coral cuerno de alce) y de $A$. cervicornis (coral cuerno de venado). A inicios de la década de 1980 , la cubierta coralina viva de $A$. cervicornis era $>21 \%$ en varios sitios alrededor de Discovery Bay, pero para 1987 había declinado a menos de 1\%. No se reestablecieron poblaciones grandes de Acropora en la vecindad del Discovery Bay por casi dos décadas. En 1995, la cubierta de A. cervicornis en Dairy Bull Reef (DBR) era de $0.6 \%$ y aumentó a cerca de $10.5 \%$ en 2004. Para 2005, la cobertura de $A$. cervicornis aumentó hasta $44 \%$. Este aumento en la cobertura de $A$. cervicornis es parte de una importante "reversión de fase" informado por Idjadi et al. en 2006. Una población aislada de $A$. cervicornis exhibió una cobertura coralina similar en Río Bueno (ERB). En 2005, ambas poblaciones del A. cervicornis se blanquearon. Sin embargo, las dos poblaciones respondieron de manera diferente. El blanqueamiento diezmó la población de A. cervicornis en DBR; los sobrevivientes fueron atacados por Coralliophilia, y la cobertura A. cervicornis 
habia declinado a $<0.5 \%$ en junio 2006. La población en ERB se recuperó del blanqueamiento con una disminución mínima en la cobertura de coral. El reclutamiento coralino fue examinado durante tres períodos de reproducción en DBR. Solamente hallamos dos reclutas de Acropora en los azulejos - uno en 2003 y otro en 2005. Los Acropora representaron solamente el $0.7 \%$ del total de reclutas en los azulejos durante todo el período de muestreo.

Palabras claves: Acropora cervicornis, restauración, reclutamiento, plánula.

\section{REFERENCES}

Bruckner, A.W., R.J. Bruckner \& E.H. Williams Jr. 1997. Spread of black-band disease epizootic through the coral reef system in St. Ann's Bay, Jamaica. Bull. Mar. Sci. 61: 919-928.

Crawford, J.A. 1995. The effects of Hurricane Allen at Discovery Bay, Jamaica, and a post-hurricane survey of the living hermatypic corals. Carib. J. Sci. 31: 237-242.

Goreau, T.F. \& J.W. Wells. 1967. The shallow-water Scleractinia of Jamaica: revised list of species and their vertical distribution range. Bull. Mar. Sci. 17: $442-453$.

Goreau, T.F. \& N.I. Goreau. 1973. The ecology of Jamaican reefs II. Geomorphology, zonation and sedimentary phases. Bull. Mar. Sci. 23: 399-464.

Goreau, T.J. 1992. Bleaching and reef community change in Jamaica: 1951-1991. Amer. Zool. 32: 683-695.

Goreau, T.J, R.L. Hayes, J.W. Clark, D.J. Basta \& C.N. Robertson. 1993. Elevated sea surface temperatures correlate with Caribbean coral reef bleaching. pp. 225-255, In R.A. Geyer (ed.) A Global Warming Forum: Scientific, Economic and Legal Overview. CRC Press, Boca Raton, Florida, USA.

Gleason, D.F. \& G.M. Wellington. 1993. Ultraviolet radiation and coral bleaching. Nature 365: 836-838.

Hodgson, G. \& J. Liebeler. 2002. The Global Coral Reef Crisis Trends and Solutions. Reef Check Foundation, Los Angeles, California, USA. 79 p.

Hughes, T.P. 1994. Catastrophes, phase shifts and largescale degradation of a Caribbean coral reef. Science 265: $1547-1551$.

Idjadi, J.A., S.C. Lee, J.F. Bruno, W.F. Precht, L. AllenRequa \& P.J. Edmunds. 2006. Rapid phase shift reversal on a Jamaican coral reef. Coral Reefs 25: 65-68.
Jokiel, P.L. 1980. Solar ultraviolet radiation and coral reef epifauna. Science 207: 1069-1071.

Knowlton, N., J.C. Lang \& B.D. Keller. 1990. Case study of natural population collapse: post hurricane predation of Jamaican staghorn corals. Smithson. Contrib. Mar. Sci. 31: 1-25.

Kojis, B.L. \& N.J. Quinn. 1993. Biological limits to Caribbean reef recovery. A comparison with western South Pacific reefs. Pp. P35-P41. In R.N. Ginsburg (compiler). Global Aspects of Coral Reefs, Health, Hazards, and History, Miami, Florida, USA.

Kojis, B.L. \& N.J. Quinn. 2001. The importance of regional differences in hard coral recruitment rates for determining the need for coral restoration. Bull. Mar. Sci. 69: 967-974.

Knowlton, N., J.C. Lang, C.M. Rooney \& P. Clifford. 1981. When hurricanes kill corals: evidence for delayed mortality in Jamaican staghorns. Nature 294:251-252.

Miller, J., R. Waara, E. Muller \& C. Rogers. 2006. Coral bleaching and disease combine to cause extensive mortality on reefs in US Virgin Islands. Coral Reefs 25:418.

Sammarco, P.W. 1980. Diadema and its relationship to coral spat mortality: Grazing, competition, and biological disturbance. J. Exp. Mar. Biol. Ecol. 45: 245-272.

Rylaarsdam, K.W. 1983. Life histories and abundance patterns of colonial corals on Jamaican reefs. Mar. Ecol. Prog. Ser. 16: 249 - 263.

Quinn, N.J. \& B.L. Kojis. 1999. Case studies of natural variability in coral recruitment from the Caribbean and Pacific. Which reefs need restoration assistance? Pp. 159. In Proc. Int. Conf. on Scientific Aspects of Coral Reef Assessment, Monitoring and Restoration, Ft. Lauderdale, Florida, USA.

Quinn, N.J. \& B.L. Kojis. 2003a. Variation in subsurface seawater temperature off Discovery Bay, Jamaica and the U.S. Virgin Islands. Rev. Biol. Trop. 51 (Suppl. 4): 181-187.

Quinn, N.J. \& B.L. Kojis. 2003b. The dynamics of coral reef community structure and recruitment patterns around Rota, Saipan, and Tinian, Western Pacific. Bull. Mar. Sci. 53: 646-661.

Quinn, N.J. \& B.L. Kojis. 2005. Patterns of sexual recruitment of acroporid coral populations on the West Fore Reef at Discovery Bay, Jamaica. Rev. Biol. Trop. 53 (Suppl. 1): 83-90. 
Quinn, N.J. \& B.L. Kojis. 2006a. Natural variability in the recovery of reef ecosystems. Pp. 83-97. In W.F. Precht (ed.). Reef Restoration Handbook - The Rehabilitation of an Ecosystem Under Siege. CRC Press, Boca Raton, Florida, USA.

Quinn, N.J. \& B.L. Kojis. 2006b. Evaluating the potential of natural reproduction and artificial techniques to increase Acropora cervicornis populations at Discovery Bay, Jamaica. Rev. Biol. Trop. 54 (Suppl. 3): 105-116.

Tunnicliffe, V. 1981. Breakage and propagation of the stony Acropora cervicornis. Proc. Natl. Acad. Sci. 78: 2427-2431.
Tunnicliffe, V. 1983. Caribbean staghorn coral populations: Pre-Hurricane Allen conditions in Discovery Bay, Jamaica. Bull. Mar. Sci. 33: 132-151.

Wapnick, C., W.F. Precht \& R.B. Aronson. 2004. Millennialscale dynamics of staghorn coral in Discovery Bay, Jamaica. Ecol. Lett. 7: 3564-361.

Woodley, J.D. 1991. The effects of Hurricane Gilbert on coral reefs At Discovery Bay. In UNEP Regional Seas Reports and Studies, No. 110. Appendix 9.

Woodley, J.D., E.A. Chornesky, P.A. Clifford, J.B.C. Pearson, J.W. Porter, M.C. Rooney, K.W. Rylaarsdam, V.J. Tunnicliffe, C.M. Wahle, J.L. Wulff, A.S.C. Curtis, M.D. Dallmeyer, B.P. Jupp, M.A.R. Koehle, J. Niegel \& E.M. Sides. 1981. Hurricane Allen's Impact on Jamaican Coral Reefs. Science 241: 749-755. 
